\title{
Enhancing The National Map Through Tactical Planning and Performance Monitoring
}

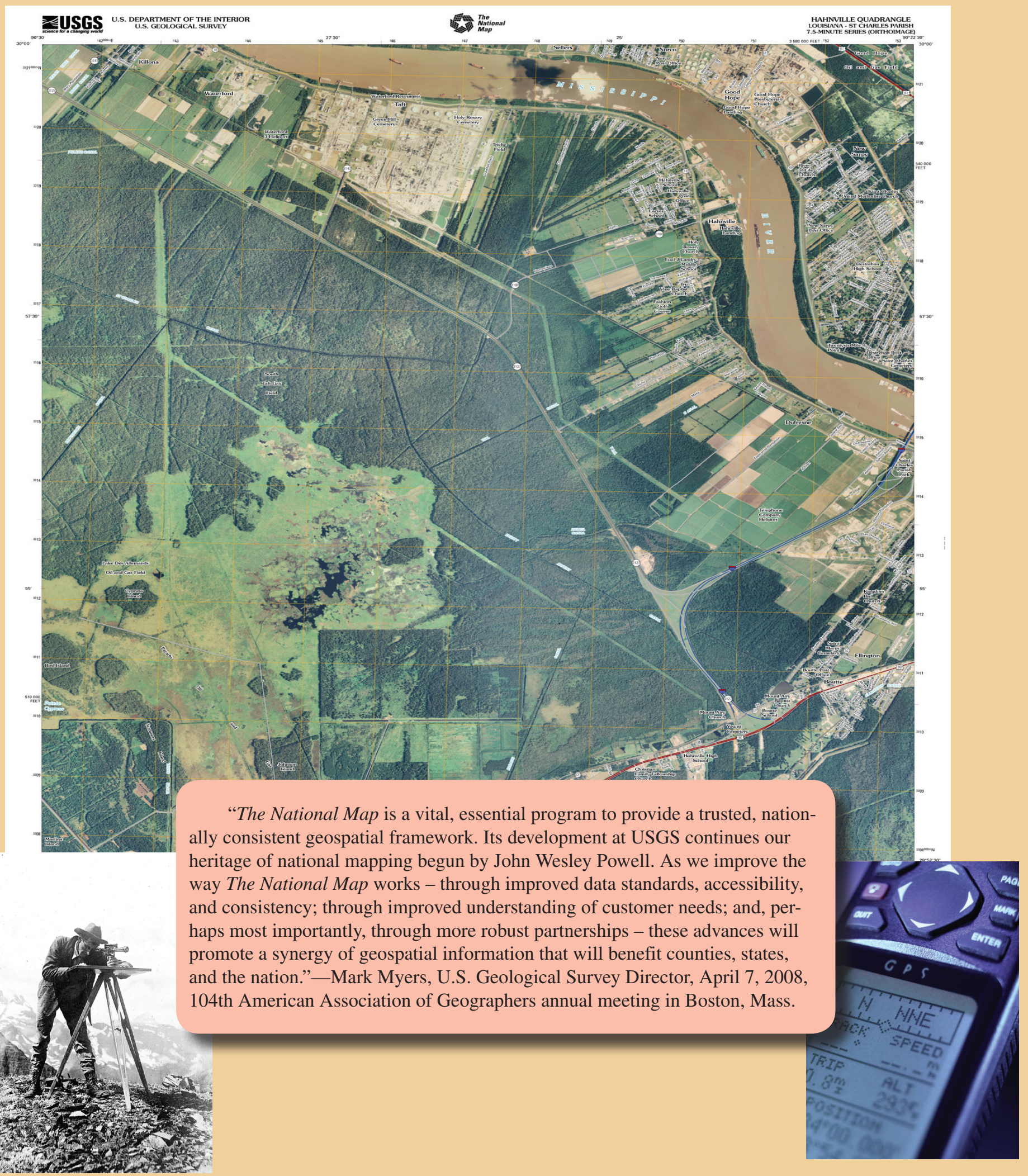




\section{The National Map Tactical Performance Planning Summary for Fiscal Years 2008 and 2009}

Tactical planning and performance monitoring are initial steps toward improving "the way The National Map works" and supporting the U.S. Geological Survey (USGS) Science Strategy. This Tactical Performance Planning Summary for The National Map combines information from The National Map 2.0 Tactical Plan and The National Map Performance Milestone Matrix. The National Map 2.0 Tactical Plan is primarily a working document to guide The National Map program's execution, production, and metrics monitoring for fiscal years (FY) 2008 and 2009. The Tactical Plan addresses data, products, and services, as well as supporting and enabling activities. Tactical Plan goals and deliverables will be balanced with financial as well as other resources through plan management. The Performance Milestone Matrix contains the full list of milestones, major deliverables, and major tasks for The National Map and forms the basis for reporting on accomplishments and issues.

The National Map's 2-year goal for FY 2008 and FY 2009 is to provide a range of geospatial products and services that further the National Spatial Data Infrastructure and underpin USGS science. To do this, the National Geospatial Program will develop a renewed understanding during FY 2008 of key customer needs and requirements, develop the infrastructure to support The National Map business model, modernize its business processes, and reengineer its workforce. The USGS collaborates with a broad range of customers and partners who are essential to the success of The National Map, including the science community, State and Federal agencies involved in homeland security, planners and emergency responders at the local level, and private companies. Partner contributions and data remain a primary input to and foundation of The National Map. Partnerships with State, Federal, and local agencies and industry will enhance the USGS capacity to acquire and steward 1:24,000scale or better data into The National Map. The data will be used to modernize the cornerstone 7.5-minute topographic map series for the Nation.

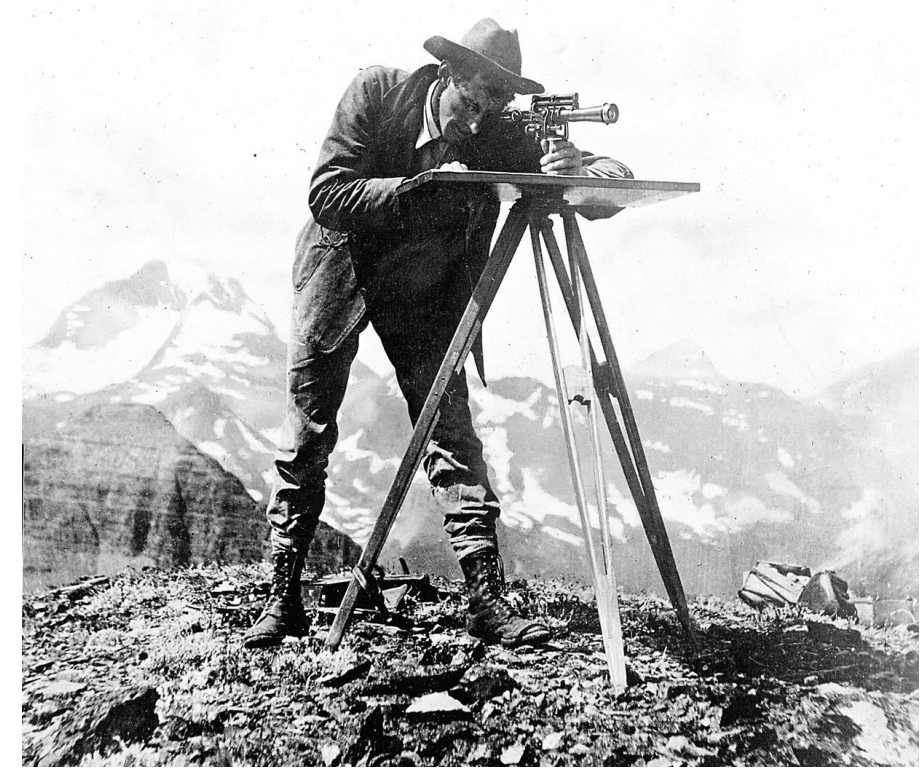

Figure 1. Herbert "Shortie" Clark mapping with a plane table and telescopic alidade in the early 1900s.

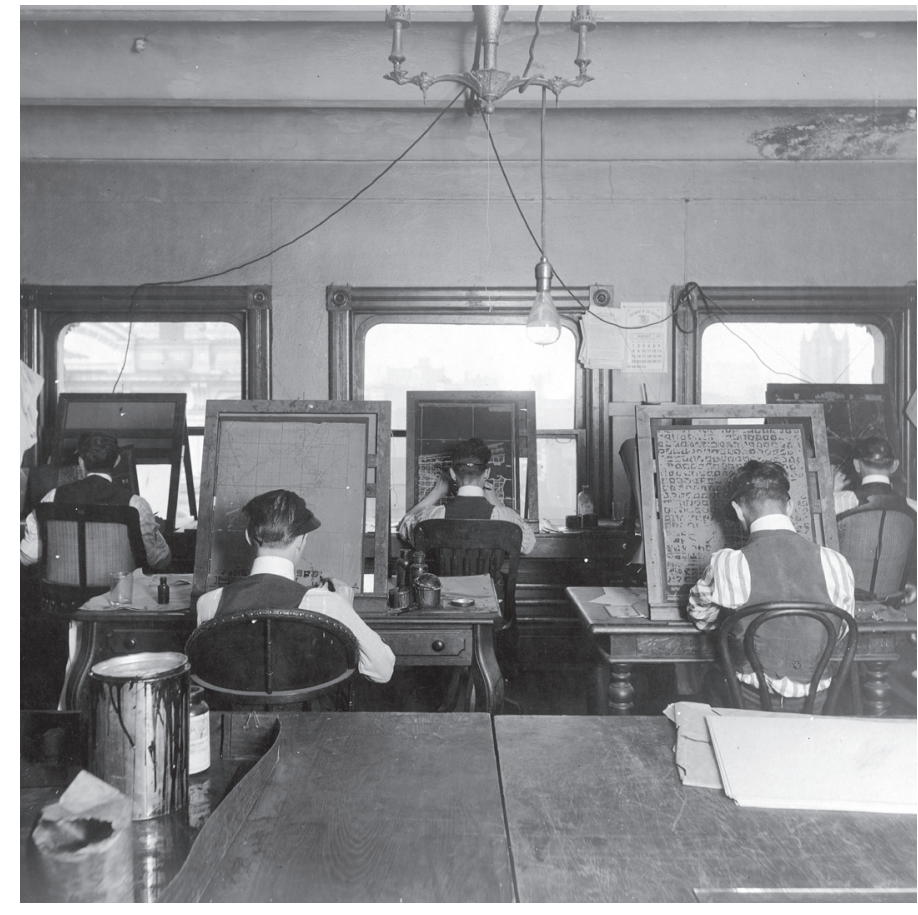

Figure 2. USGS employees scribing copper plates for map production in 1917.

The integration of data is critical to the success of The National Map. The approach to integration will be determined by assessing standards and available resources. The edited data must be preserved and corrections passed back to the source. An integration team will be established to plan for and coordinate the horizontal and vertical integration of data and reestablish the capabilities through the National Geospatial Technical Operations Center.

Priorities for The National Map have been established for those activities most important to the short- and long-term success of The National Map. These priorities help to focus work, management, and the distribution of resources within the project. Priorities will be adjusted if necessary to respond to changes to the project that may impact resources, constrain timeframes, or change customer needs. Priorities are set and adjusted on the basis of a collaborative process involving leadership, management, technical leads, customers, partners, and others. That process involves identification of a driver (need for a change); an assessment of impact; identification of cost, risk, and requirements; and establishment of responsibility and timeframes for deliverables. The collaborative process results in the submission of a proposal to a Change Management Board. Any changes require final management approval and are fully documented. In FY 2008 and FY 2009, The National Map will focus on (1) the priority areas of the East Coast and Gulf Coast States, two counties (50 miles) deep from the coastline and from international boundaries with Canada and Mexico; (2) 133 urban areas; (3) the Department of the Interior's high-priority lands programs; (4) USGS science initiatives; and (5) areas where current data are available for the eight data themes on which The National Map focuses. The National Map will hold data in centrally managed databases to improve availability and performance while controlling costs. 


\section{Data Products and Services}

In the context of The National Map, products are information assets with specified characteristics and qualities delivered to consumers in electronic, or in some emergency cases paper, formats. Services are functional capabilities provided to The National Map consumers that support a sustained interaction with The National Map data and computing assets. The National Map products and services are designed to satisfy consumer-initiated geospatial or mapping requests or inquiries. The product and service directory can be found at http://www. usgs.gov/ngpo (click on "Reading Room").

\section{Elevation}

The USGS is designated by the Office of Management and Budget (OMB) Circular A-16 as the lead agency for elevation data. Three hundred and eighty-four quadrangles of data are planned to be produced per quarter (Q) in FY08, and 400 quadrangles of data per quarter are planned in FY09. The National Map will hold 10-meter or finer elevation data in the National Elevation Dataset, covering 100 percent of the priority areas by the end of FY09. Working with partners, the USGS will update an additional 500 quadrangles of 10-meter or finer elevation data, which will be published in the National Elevation Dataset. The elevation team will work with the graphics and systems teams to develop automated contour generation by the end of the first quarter of FY09. This work will develop requirements in FY08Q1, drafting an automated contour plan and specifications in FY08Q2 to be finalized in FY08Q4, and implementing the contour plan in FY09Q1. A revision of elevation specifications will begin with a review in FY08Q1, followed by revised specification in FY08Q3 to be adopted in FY08Q4. Downloads are available at http://ned.usgs.gov.

\begin{tabular}{llllll}
\hline \multirow{2}{*}{ Fiscal year } & \multicolumn{5}{c}{ Number of quadrangles } \\
\cline { 2 - 6 } & $\mathbf{0 1}$ & $\mathbf{0 2}$ & $\mathbf{0 3}$ & $\mathbf{0 4}$ & Total \\
\hline 2008 & 384 & 384 & 384 & 384 & 1,536 \\
2009 & 400 & 400 & 400 & 400 & 1,600 \\
\hline
\end{tabular}

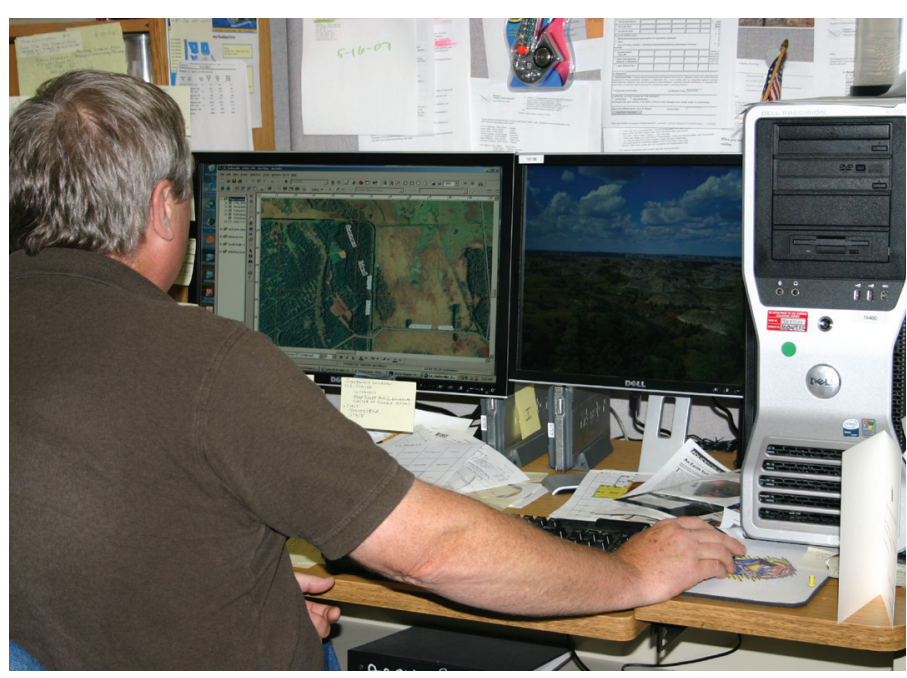

Figure 3. Geospatial information specialist digitally processes imagery in 2008.

\section{Geographic Names}

The USGS is designated by OMB Circular A-16 as the lead for geographic feature names and is the authoritative source for geographic names usage throughout the Federal Government. The National Map will collect 2,500 selected administrative features along the East Coast in each quarter of FY08 and along the Gulf Coast in each quarter of FY09. The Geographic Names Team will work with USGS Geospatial Liaisons to establish partnership agreements to integrate the Geographic Names Information System with State Geographic Information Systems and (or) to steward data for one State in each quarter during FY08 and the first quarter of FY09 and two States in the final three quarters of FY09. Names of administrative features will be updated along the East Coast by the end of FY08. It is a National Geospatial Program Office goal to have agreements in place for Google Earth to use and credit USGS Geographic Names by the end of the first quarter of FY08. Downloads are available at http://geonames.usgs.gov.

\begin{tabular}{lccccc}
\hline \multirow{2}{*}{ Fiscal year } & \multicolumn{5}{c}{ Number of features } \\
\cline { 2 - 6 } & $\mathbf{0 1}$ & $\mathbf{0 2}$ & $\mathbf{0 3}$ & $\mathbf{0 4}$ & Total \\
\hline 2008 & 2,500 & 2,500 & 2,500 & 2,500 & 10,000 \\
2009 & 2,500 & 2,500 & 2,500 & 2,500 & 10,000 \\
\hline
\end{tabular}

\section{Hydrography}

The USGS is designated by OMB Circular A-16 as the lead for hydrographic units, which are comprehensive sets of digital spatial data that represent the surface water of the United States using common features such as streams, rivers, canals, ponds, lakes, and oceans. All of the hydrography in The National Map will be upgraded to the interim design standard by the end of FY08 by updating 450 subbasins of hydrographic data each quarter. Updating 565 subbasins during each quarter in FY09 will result in 25 percent of the hydrography being upgraded to the final design standard by the end of FY09. Stewardship partners will upgrade 25 percent of the The National Map's hydrography by updating 96 subbasins per quarter. Fifteen stewardship agreements will be developed in FY08 (Q1, 5; Q2, 3; Q3, 3; Q4, 4) and 30 in FY09 (Q1, 5; Q2, 5; Q3, 10; Q4, 10). Downloads are available at http://nhd.usgs.gov.

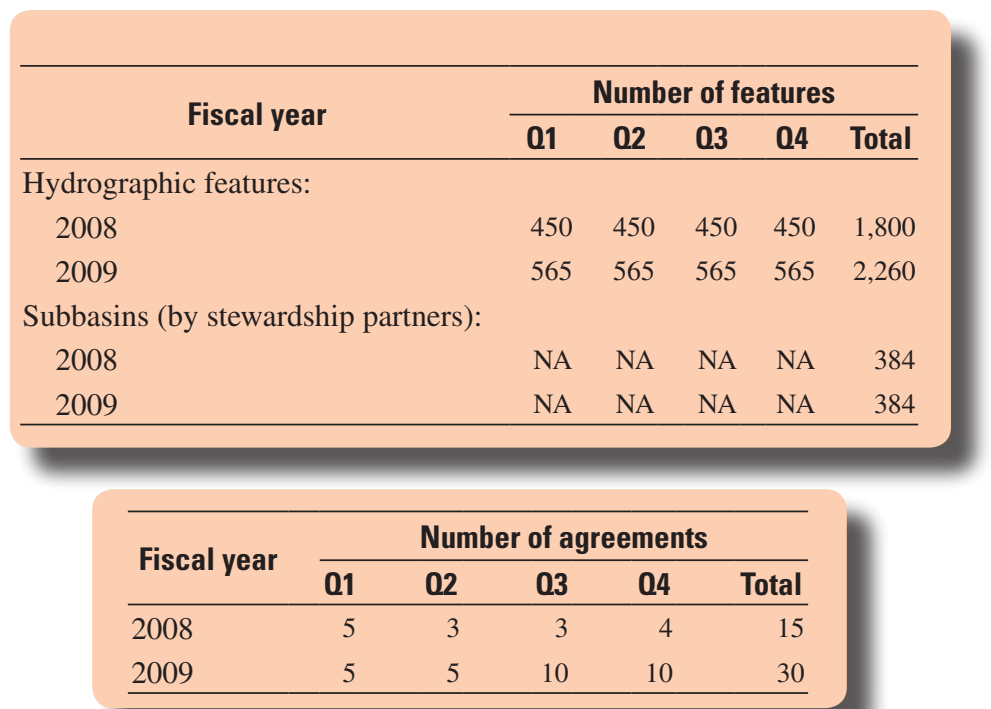


Land Cover (Responsibility of the Geography Discipline)

The USGS is designated by OMB Circular A-16 as the lead for land cover data. The National Map will use the National Land Cover 2001 database for land cover data. Beginning in FY09, the Land Cover program will begin production of the National Land Cover Database 2006 update. Production will take 18 to 24 months and will depend on member contributions from the Multi-Resolution Land Cover Characteristics Consortium. National Land Cover Database 2006 update products include percentage of canopy and percentage of impervious surface for National Geospatial Program high-priority areas, to be completed by September 30, 2009. National Land Cover Database 2006 processed data will be updated beginning in 2009, with completion scheduled by March 31, 2010. Downloads are available at http://landcover.usgs.gov.

\section{Orthoimagery}

The USGS shares the Circular A-16 lead for orthoimagery with the Department of Agriculture. The standard for orthoimagery data is digital orthorectified imagery of 1-meter groundcover sample distance resolution or better, acquired in a 5-year cycle for the United States and its territories and possessions, and digital orthorectified imagery of 1-foot groundcover sample distance resolution or better, acquired in a 2- to 4-year cycle for the 133 urban areas as defined in the Homeland Security Infrastructure Program (HSIP) Tiger Team Report of 2002. The National Map will acquire or update 1,377 quadrangles of data during each quarter of FY08 and FY09. Downloads are available at http://gisdata.usgs.net/website/Orthoimagery.

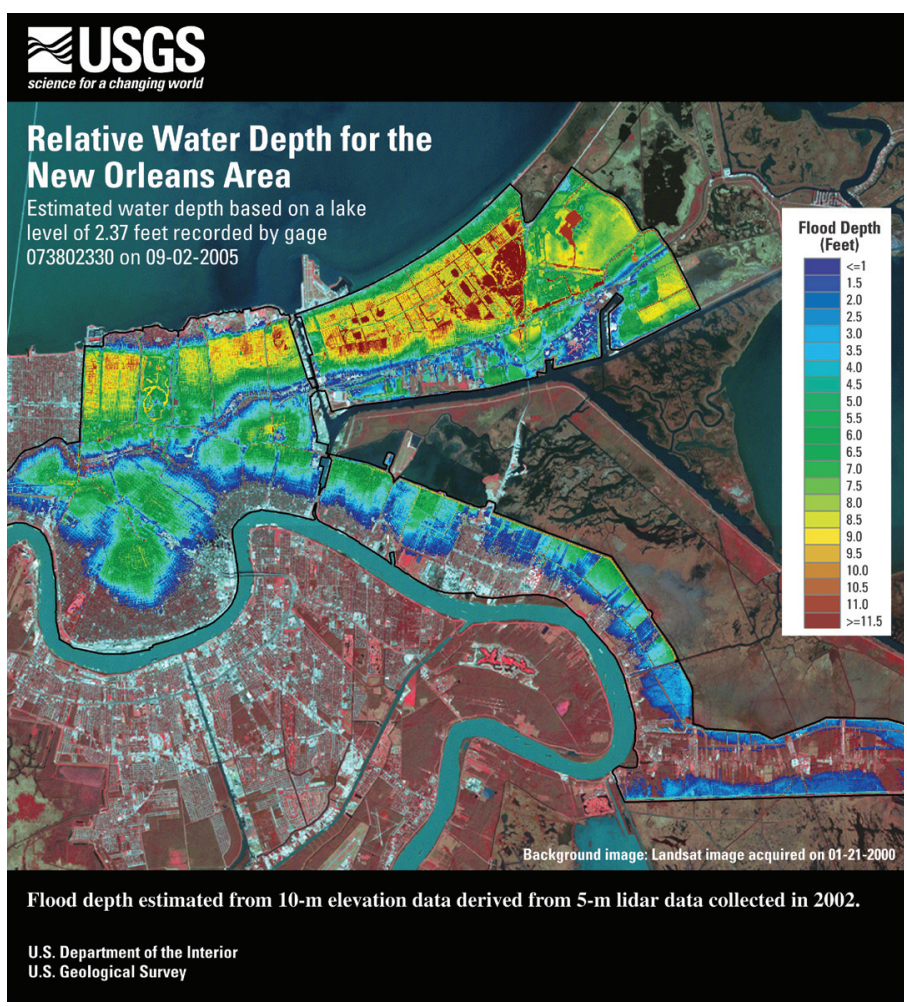

Figure 4. The National Map data support recovery efforts after Hurricane Katrina.

\section{Boundaries (Governmental Units)}

The USGS is not the Circular A-16 lead for boundaries (governmental units), which depict administrative and jurisdictional information. Federal boundaries will be updated for 600 counties in FY08 (Q2, 150; Q3, 200; Q4, 250) and 300 counties in each quarter of FY09. Census data will be used to update 550 counties in FY08 and 750 counties in FY09 and are dependent upon when the Census Bureau makes the information available. Downloads are available at http://bpgeo.cr.usgs.gov.

\begin{tabular}{lllllr}
\hline \multirow{2}{*}{ Fiscal year } & \multicolumn{5}{c}{ Number of boundaries } \\
\cline { 2 - 6 } & $\mathbf{0 1}$ & $\mathbf{0 2}$ & $\mathbf{0 3}$ & $\mathbf{0 4}$ & Total \\
\hline Federal: & & & & & \\
2008 & NA & 150 & 200 & 250 & 600 \\
2009 & 300 & 300 & 300 & 300 & 1,200 \\
Counties: & & & & & \\
2008 & NA & NA & NA & NA & 550 \\
2009 & NA & NA & NA & NA & 750 \\
\hline & & & & & \\
\hline
\end{tabular}

\section{Structures}

The USGS is not the Circular A-16 lead for structures, which depicts the geospatial location, classification, and other characteristics of manmade facilities. National coverage at a 1:24,000-scale for essential facilities, including hospitals, schools, police stations, and fire stations, will be available by December 31, 2008. Data will be updated for 650 counties in FY08 (Q1, 50; Q2, 100; Q3, 200; Q4, 300) and 1,900 counties in FY09 (Q1, 400; Q2, 500; Q3, 500; Q4, 500). Downloads are available at http://bpgeo.cr.usgs.gov.

\begin{tabular}{lrlllr}
\hline \multirow{2}{*}{ Fiscal year } & \multicolumn{6}{c}{ Number of structures } \\
\cline { 2 - 6 } & $\mathbf{0 1}$ & $\mathbf{0 2}$ & $\mathbf{0 3}$ & $\mathbf{0 4}$ & Total \\
\hline 2008 & 50 & 100 & 200 & 300 & 650 \\
2009 & 400 & 500 & 500 & 500 & 1,900 \\
\hline \multicolumn{7}{c}{} \\
\hline
\end{tabular}

\section{Transportation}

The USGS is not the Circular A-16 lead for transportation, which consists of the geographic locations, interconnectedness, and characteristics of roads, railroads, airports, and other associated transportation features. Census data will be used to achieve national coverage of road data by December 31, 2008. Twenty percent of the Nation will be under active stewardship for roads data by December 31, 2008. The National Map will work with providers of other transportation data, including airports, pipelines, trails, and railroads, to develop nationally maintained and integrated geospatial data inventories. Pilot projects will be developed in five States to test and implement data exchange workflows between State implementations and The National Map. Transportation will incorporate Emergency-911 and evacuation-route content in support of disaster response capabilities. Downloads are available at http://bpgeo.cr.usgs.gov. 


\section{Supporting and Enabling Activities}

Supporting and enabling activities make it possible to produce the products and services of The National Map. They include partnership activities, improved compatibility of systems, outreach, and integration of data themes. During the 2-year period, the following supporting and enabling activities will take place.

\section{Partnerships in Support of Products and Services}

Data acquisition efforts, footprints, specifications, and work priorities will be aligned with a joint schedule and plans for The National Map. USGS Geospatial Liaisons will develop The National Map-aligned business plan focused on data inventory, discovery, and acquisition for each State by the end of the third quarter of 2008. During FY09, 79 (Q1, 5; Q2, 14; Q3, 35; Q4, 25) partnerships will be established or revised. Feedback on products and services will be collected from partners and customers. The USGS Geospatial Liaisons will provide outreach and support for The National Map Tactical Plan and its products and services through $54(\mathrm{Q} 1,9$; Q2, 18; Q3, 16; Q4, 11) presentations to regional executive science centers in FY08. A business case analysis in FY09 will evaluate hosting partner data in native format.

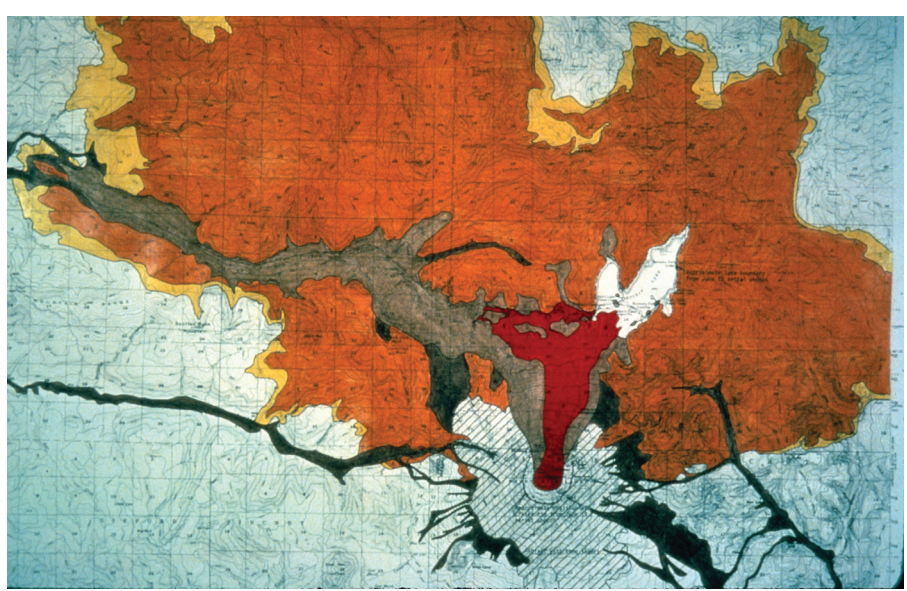

Figure 5. Scientists integrate flowage deposits from 1980 Mount St. Helens eruption with base topographic data from The National Map.

\section{Systems in Support of Products and Services}

The National Map shared (common) systems Phase I activities in FY08 address immediate needs for products and services. Each of the following efforts follows a schedule incorporating a statement of need, project plan, requirements, design, acceptance, and deployment. The Agreements Management System will be completed by December 31, 2008. The Performance Management and Status System will be completed by September 30, 2008. Portal and User Interface Improvements (Geospatial OneStop and The National Map) will be completed by December 31, 2008. Data Integration Strategy and Technical Approaches will be developed by September 30, 2008. Improvements to The National Map Architecture will be made by September 30, 2008. During FY08, Phase II requirements will be evaluated and work planned for FY09 and beyond. Other system activities include Web Mapping Services (WMS), Web Feature Services (WFS), Web Coverage Services (WCS), Data Catalogs, a data partnership Marketplace, and Data Theme Status Graphics. A quarterly deliverable schedule for systems work is available on request.
Outreach and Communications in Support of Products and Services

Accurate and clear communication is important if the geospatial data community is to support the building, maintenance, and use of The National Map through partnerships. Activities include establishing criteria for comprehensive and specific training, workshop, focus group, fact sheet, and promotional item requirements; coordinating the theme-driven outreach activities with the broader National Geospatial Program activities; ensuring that outreach efforts, as appropriate, are coordinated with the USGS Office of Communications; developing an individual life cycle for The National Map fact sheets; and crafting specific messages targeted to specific audiences. The outreach team will finalize a communication plan during the third quarter of FY08. During the fourth quarter the outreach team will provide the communication plan to the USGS audience. A feedback mechanism for National Geospatial Program Office employees to report successes will be in place by the end of the first quarter of FY09, and the National Geospatial Program Office Web site will contain approved briefing materials by the end of the second quarter.

\section{Integration of Data Themes in Support of Products and Services}

The integration of data is critical to the success of The National Map. For national data sets to be readily suited for producing integrated data products or for performing sound scientific studies, they must be reasonably current and complete, nationally consistent, and properly integrated. Horizontal integration within The National Map ensures nationwide seamlessness and consistency within each data theme. Vertical integration ensures that the spatial relationship of features across The National Map's data themes will be the same that those features have in the real world or on the ground. The implementation of an acceptable data-integration process will require development of efficient interactive data editing tools. The edited data must be preserved, and mechanisms must also be established to send updates made by the USGS back to the authoritative source for any particular dataset. An integration team established during FY08 is planning for and coordinating the integration of data.

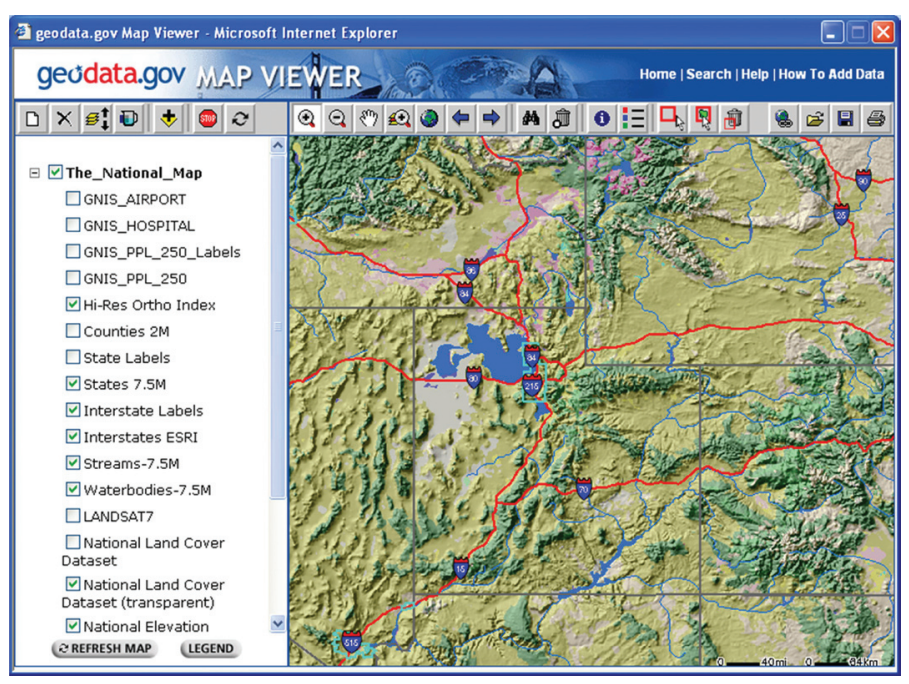

Figure 6. Geospatial One-Stop displays The National Map data through a map viewer. 


\section{Map Products and Services}

\section{Scanned 7.5-Minute Topographic Maps}

The USGS is making previously published (printed) versions of USGS primary base series topographic maps available by scanning the prints and converting the resulting image files to high-resolution, georeferenced pdfs. Approximately 3,000 7.5-minute quadrangles covering the East Coast and Gulf Coast States will be scanned and converted to high-resolution, georeferenced pdfs by December 31, 2008. Approximately 250 additional 7.5-minute high-resolution, georeferenced pdfs will be created across the United States to support printon-demand for low-selling, out-of-stock quadrangles and a to-be-determined quantity of high-resolution, georeferenced pdfs from the USGS library in Reston, Va. (early FY08). The scanned maps are available through the USGS Store at http://store.usgs.gov (click on "Map Locator").
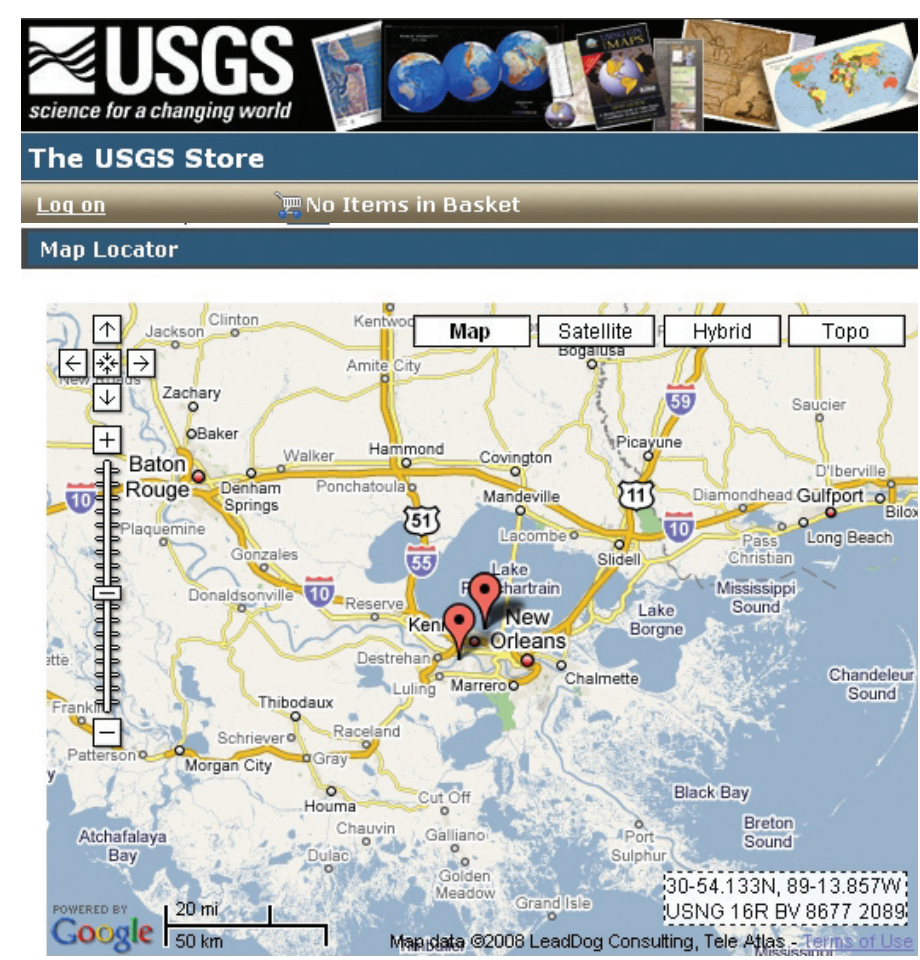

Figure 7. Find maps using the Map Locator at the USGS Store.

\section{5-Minute Digital Topographic Maps}

The National Map will produce 1:24,000-scale georeferenced pdf digital topographic map products from The National Map data with contours, hydrography, transportation, boundaries, structures, geographic names, and land cover in the customary 7.5-minute by 7.5-minute tile-based format. An orthoimagery layer can optionally be turned on or off at the click of a box. The quality of the digital product will improve as the accuracy, currentness, and completeness of the data improve.
Product specifications will be developed with customer input on prototype products received by the end of the first quarter of FY09. A streamlined production process will be developed by the end of the first quarter of FY09 and 177 quadrangles will be produced in the final three quarters of FY09.

\section{Image Maps with Selected Overlays}

The National Map will produce orthoimage maps at the $1: 24,000$ scale from the best available orthoimagery framed with a 7.5-minute by 7.5-minute projection line and with sufficient labels to help orient the user within the image. In priority areas, 1,734 1:24,000-scale image maps with selected overlays two counties deep ( 50 miles) along the Atlantic Coast (Florida to Delaware) and the Gulf Coast (Florida to Texas) will be produced in FY08 (Q1, 240; Q2, 498; Q3, 498; Q4 498) and 498 in the first quarter of FY09, on the basis of written specifications. Full automation of image map production will allow image maps to be rapidly produced for emergency response needs by the end of the first quarter of FY09. An image map standard will be approved in the first quarter of FY08, and customer feedback on the new product will be gathered during the third quarter of FY08, after which the image maps will be prepared for release to the public and available at http://store.usgs.gov.

\begin{tabular}{lllllr}
\hline \multirow{2}{*}{ Fiscal year } & \multicolumn{5}{c}{ Number of image maps } \\
\cline { 2 - 6 } & $\mathbf{0 1}$ & $\mathbf{0 2}$ & $\mathbf{0 3}$ & $\mathbf{0 4}$ & Total \\
\hline 2008 & 240 & 498 & 498 & 498 & 1,734 \\
2009 & 498 & NA & NA & NA & 498 \\
\hline
\end{tabular}

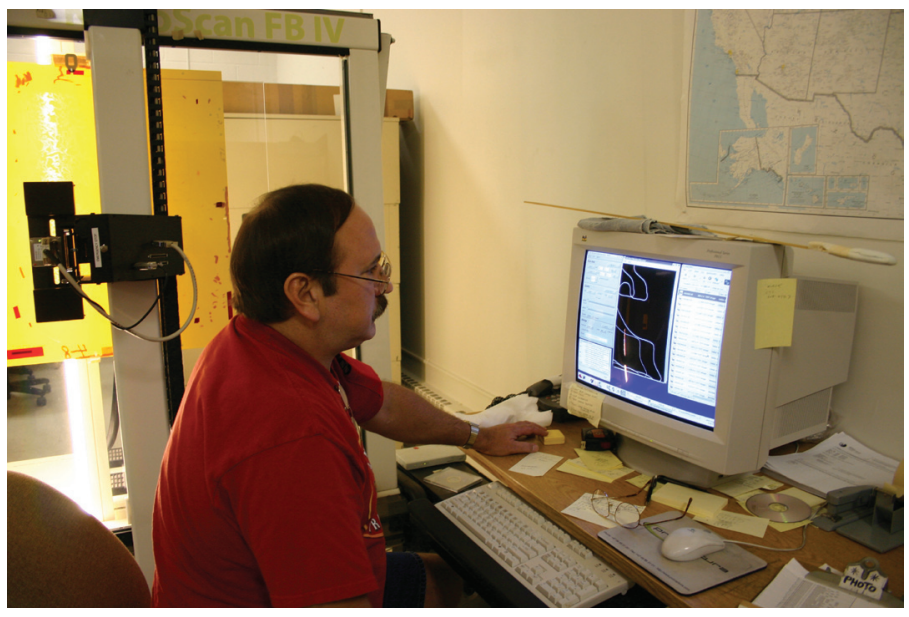

Figure 8. Cartographer creates contours for a digital map using scanning and digital processing.

\section{For more information, contact:}

nationalmap@usgs.gov

\section{Comments and Suggestions}

"The National Map Tactical Performance Planning Summary for Fiscal Years 2008 and 2009" is a dynamic, working document. Your comments and suggestions are welcome at http://www.usgs.gov/ngpo/tnm_tacticalplan.html. 